\title{
Ruhsal Liderlik ve Eğitimdeki Yansımaları ${ }^{1}$
}

DOI: $10.21666 /$ muefd.325111

\author{
Abbas ERTÜRK \\ Muğla Sitkı Koçman Üniversitesi abbaserturk@mu.edu.tr \\ Emrah Dönmez \\ Muğla Sıtkı Koçman Üniversitesi emrahdonmez123@gmail.com
}

Özet

Ruhsal liderlik, temelinin ruh ve ruhsallık kavramlarl üzerine oturtulduğu görülmektedir. Ruhsal liderlik, insanların çalı̧̧ma ortamlarındaki ruhsal durumlarının da göz önünde bulundurulması gerektiği düşüncesinden ortaya çıkmıştır. Ruhsal liderliğin savunucularına göre insan sadece fiziki varlıktan ibaret olarak görülmemelidir. Insanoğlunun çalışma hayatı ve verimliliği fiziksel yönü kadar ruhsal yönü ile de ilgilidir. Ruhsal liderlik üzerine farklı ülkelerde yapılmış birçok araştırma ve alan yazında hakkında yazılmış birçok makale olsa da, Türkiye'de çok fazla çalışılmış bir konu değildir. Bundan dolayı bu çalışmanın amacı ruhsal liderliği daha anlaşılır kılabilmek ve ruhsal liderliğin genel yapısını açıklamaktır. Araştırmada literatür tarama yöntemi kullanılmıştır. Araştırma yapılırken herhangi bir sınırlama getirilmemiş erişilebilen tüm kaynaklar taranmıştır. Araştırma sonucunda yaygın olarak literatürde geçen iki farklı liderlik modeli saptanmıştır.

Anahtar sözcükler: Ruhsallık liderlik, Ĕgitim, Öğretmen

\section{Spiritual Leadership And Its Reflections On Education}

\begin{abstract}
It is seen that the spirit and spirituality are the basis of spiritual leadership. Spiritual leadership has been arised out of the thought that spiritual conditions of people should also be considered in the work environment. According to the supporters of spiritual leadership, human shouldn't be seen just as a physical asset. Humankind's working life and productivitiy are as related to spiritual sides as physical asset. Even if many studies have been done on spiritual leadeship at other counries and there are many articles written about it in the literature, there are few studies about it in Turkey. That is why, the aim of this study is to make spiritual leadership understandable and make its outline clear. In the present study, literature research technique has been used. When researching, all available sources have been reviewed. According to the findings of research, it has been found out two different models used commonly in the literature. One of these models is the Fairholm model and the second is the Fry model.
\end{abstract}

Key words: Spiritual Leadership, Education, Teacher

Liderlik tanımlaması zor bir kavramdır ve liderliğin evrensel tek bir tanımı yoktur. Liderin kim olduğu ve liderin nasıl olunabileceği açık ve net değildir. Liderlik farklı koşullarda farklı tanımlara bürünebilmektedir (Aslan, 2013). Bass (1990a) liderliği, bir grup süreci, bir kişilik meselesi, etkileme, ikna etme, güç ilişkileri, örgütsel amaçlara ulaşma aracı, yapının kurulması ya da tüm bu davranışların bir bileşimi olarak ifade etmektedir (akt: Güçlü, 2016). Zaleznik (1977)'e göre liderlik, izleyenlerinin

\footnotetext{
${ }^{1}$ Bu çalışma, Mayıs 2017 de gerçekleştirilen II. Uluslararası Felsefe Eğitim Sanat ve Bilim Tarihi Sempozyumunda sunulmuştur.
} 
düşüncelerini etkilemek ve dikkatini çekebilmek için güç kullanmaktır. Liderlik sadece çalışanları motive etmek için var olan bir güç değildir. Bu gücün yanısıra çalışanlara yetenek kültürü aşılamada da önemli bir güçtür ( Zafer Güneş \& Keskinkılıç Kara, 2017).

Liderliğin ortaya çıkışının medeniyetin oluşumu kadar eskiye dayandığı düşünülmektedir, çünkü medeniyetler şekillenirken bir taraftan da liderlerini şekillendirmiş ve ortaya çıkarmışlardır. Tarih boyunca dinlerden, mitolojilerden ve efsanelerden akılda kalanlar genellikle büyük liderler ve kahramanlar olmuştur (Bass, 1990b). Liderlik kavramı tarihsel olarak belli aşamalardan geçmiş ve bu aşamalara göre liderliğe farklı anlamlar yüklenmiştir. Liderlik, ilk olarak özellik kuramına göre tanımlanmıştır. Bu kuramda liderin kişisel özellikleri ön plana çıkmış ve lider olunamayacağı ancak lider doğulacağı ileri sürülmüsstür ( Ertürk 2016). Daha sonra davranış kuramı savunucuları lider olmak için sergilenmesi gereken davranışları tanımlayıp, bu davranışları sergileyenlerin lider olabileceğini belirterek liderliğin öğrenilebilecek bir olgu olduğunu öne sürmüşlerdir. Sonrasında, bu görüş de liderin içinde bulunduğu durumu göz ardı ettiği için eleştiriler almış ve liderin, örgüt ve çevre koşullarından etkileneceği öne sürülerek her liderin her ortamda başarılı olamayacağı savunulmuş̧tur. Daha sonra da liderliğe örgütlerin insani yönü de dâhil edilerek değerler liderliği ve dönüşümcü liderlik gibi yaklaşımlar ortaya atılmıştır (Bozkuş \& Gündüz, 2016). Günümüzde ise liderliğin karmaşıklığı ve kestirilemez olduğu öne sürülmektedir (Keskinkılıç Kara 2013).

\section{Ruhsal Liderlik}

Liderlikle ilgili olarak son 30 yıl içinde yeni yaklaşım ve kuramlar ortaya atılmış ve üzerinde çalışılmıştır. Bunlardan birisi de ruhsal liderliktir (Baloğlu \& Karadağ, 2009). Ruh ve ruhsallık geçmiş dönemlerde üzerinde çok konuşulmuş kavramlardır. Örgüt bağlamında ise ruhsallığa ilk olarak 1990'lı yılların başında yayımlanan Journal of Managerial Psychology, Journal of Management Inquiry, Journal of Management Education, Organization, andJournal of Organizational Change Management gibi kitap makale ve dergilerde rastlanmıştır (Hill, Jurkiewicz, Giacalone, \& Fry, 2015). Bu yıllar itibariyle ruh ve ruhsallık kavramları liderlik yaklaşımlarının içine kısmen de olsa alınmaya başlanmıştır. Ruh Temelli Liderlik, Amaç Temelli Liderlik, Bütüncül-Ruhsal Liderlik, Aşkın Liderlik ve Ruhsal Liderlik gibi ruhsal liderliğin farklı noktalarını ele alan kuramlar ortaya atılmıştır (Korkut, 2012).

Liderlik ve ruhsallık kavramlarını bir arada kullanmaya başlayan ve ruhsal liderlik teorileri geliştirmeye çalışan teorisyenlerden birisi Gilbert W. Fairholm birisi de Louis W. Fry'dır (Wharff, 2004). Fairholm (1998) yönetim alanında uygulanmak üzere ruhsal liderlik modeli geliştirmeye çalışmıştır. Bu modelde Fairholm kişiyi bir bütün olarak ele almış, kişinin sosyal, ruhsal, duygusal ve akli yönlerini birlikte değerlendirmiştir. Ruhsal liderlik, Fairholm (1998)'a göre felsefe, metafizik, din gibi birçok farklı alandan kavramı bir arada toplamaktadır ve değer temelli dönüşümcü liderlikle de yakından ilgilidir.

Blackaby, Al Arkoubi gibi bazı yazarlar ruhsal liderliği din liderliği şeklinde ele almakta ve dinle bağdaşık olarak tanımlamalar yapmaktadır. Bazı yazarlar ve kuramcılar ise evrensel değerler ile bağdaştırmaktadır (Korkut, 2012). Fry (2003) ruhsal liderliği, bir insanın kendisinin ya da başkasının ruhsal olarak ayakta kalabilmesi için özgüvenini arttırmak amacıyla gereken değerler, davranışlar ve tutumların tümü olarak tanımlamıştır. İşgörenlerin liderden beklentisi ihtiyaçlarının karşılanması üzerinedir. Ruhsal lider, işgörenlerin bu ihtiyaçlarını ruhsal ve psikolojik yönünü düşünerek hareket eden liderdir. Ruhsal liderlikle kişilerin bu ihtiyaçlarının karşılanması onların örgüte daha bağlı hale gelmesini sağlayacaktır (Fry, 2003). Bozkuş ve Gündüz (2015)'ün derlediği ruhsal liderlik özelliklerine göre ruhsal liderler etik ve prensip sahibidir, çalışanlarına değer verirler, ortak değerler oluştururlar, çalışanlarına güvenirler. Bu sayede çalışanların da birbirine güvenmeleri için güdülerler, çalışanların hayatlarını anlamlı kılmak için kalplerini kullanırlar, gelişim ve dönüşümün önündeki engelleri kaldırarak verimliliği arttırırlar, kendilerinden başlayarak etraflarını değiştirirler, çalışanların mantıklarıyla duyguları arasında köprü kuran değerler ile liderlik yaparlar ve içten güdülenmişlerdir.

$\mathrm{Bu}$ çalışmanın amacı ruhsal liderlik kavramının ortaya çıkışını, özelliklerini ve eğitim alanındaki yansımalarını araştırmaktır. Bu bağlamda aşağıdaki sorulara cevap aranmıştır.

- Ruhsal liderlik nedir? 
- Ruhsal liderlikle ilgili ortaya atılan modeller nelerdir?

- Ruhsal liderlikle ilgili Türkiye'de ve dünyada yapılan çalışmalar nelerdir?

\section{Yöntem}

$\mathrm{Bu}$ çalışma literatür taraması yöntemiyle yapılmıştır. Çalışma aşağıda verilen basamaklarla yapılmıştır.

- Liderlik ve ruhsallık kavramları incelenmiştir.

- Ruhsal liderlik kavramlarının ortaya çıkışı incelenmiştir.

- Ortaya atılan ruhsal liderlik modeller incelenmiştir.

Çalışma için gereken tarama bilimsel kitap ve makaleler üzerinden yapılmıştır. Taramalar 2016 yılında yapılmıştır. Taramalar geriye dönük erişilebilen tüm dergi makaleleri ve kitaplar taranmıştır. Taramada kullanılan kavramlar "liderlik, liderlik yaklaşımları, liderlik teorileri, ruhsal liderlik, ruhsallık, ruhsallık ve eğitim, ruhsal liderlik ve eğitim" dır. Tarama sonucunda konu kapsamı dışında olan kaynaklar elenmiş ve konu ile ilgili olan kaynaklar aranan kavramlara göre sınıflandırılmıştır. Elde edilen bulgular konuyu netleştirecek şekilde sunulmuştur.

\section{Bulgular}

$\mathrm{Bu}$ araştırmada ruhsal liderlik olgusu ile ilgili iki farklı model saptanmıştır. Araştırmanın bu bölümünde bu modellere yer verilmiştir. Bu modeller Fairholm (1998) ve Fry (2003) ruhsal liderlik modelleridir.

Fairholm (1998), topladığı unsurları kullanarak, ruhsal liderlik modelini sekiz boyut altında oluşturmaya çalışmıştır. Fairholm'a (1998) göre, bu boyutlar bir insanın neredeyse bütün yönlerini içeren bir küme şeklindedir.

Fairholm'a (1998) göre insanlar, işlerine sadece işyerlerinin onlardan beklediği bilgi, beceri ve yetenekleri için değil tüm özellikleri ile birlikte gelmek isterler. Bu tüm özellikten kasıt edilen, insanların ruhsal yönlerinin de yaptıkları işe etkisi olduğu anlamını içermektedir. Başka bir ifadeyle çalışanlar işyerlerine sadece fiziksel varlıklarıyla değil ruh halleriyle de gelmektediler. Bu nedenle çalışanın ruh hali de işyerindeki çalışmalarına etki etmektedir.

Fairholm'un (1998), ruhsal liderlik için oluşturduğu modele bakıldığında ruhsal liderliğin görevleri dikkat çekmektedir. Bu görevler yerine getirildiğinde liderliğin ana amacına ulaşmak için gerekli şartlar oluşmaktadır.

Tablo 1 Ruhsal Liderlik Unsurlart

\begin{tabular}{|l|l|}
\hline Kategoriler & Unsurlar \\
\hline Toplum & Görgü Kuralları, Kültür, Birlik ve Bütünlük \\
\hline Sürekli Gelişme & Kapasite, Kurum Sağlığı \\
\hline Yetkinlik & Denge, Güvenirlik, Güven, Güç \\
\hline Yüksek Ahlaki Standart & Olumlu onay, Ahlak, Kalp, Bütünleşme, Aşk, Varoluş, Anlam, Ahlak \\
\hline Hizmetkârlık & Özgür Bırakma \\
\hline Ruhsallık & Ortak Ruh, Duygular, Güven, Hiçbir dine bağlı olmayan ruh, İlişkiler \\
\hline Yöneticilik & Takım, Güven \\
\hline Vizyon Oluşturma & Değerler, Ruhsal Durum \\
\hline
\end{tabular}

(Fairholm, 1998) 


\begin{tabular}{lll}
\hline $\begin{array}{l}\text { Ruhsal Liderlik } \\
\text { Görevleri }\end{array}$ & Ruhsal liderlik & Temel \\
& Süreç Teknolojileri & Liderlik Hedefi \\
\hline
\end{tabular}

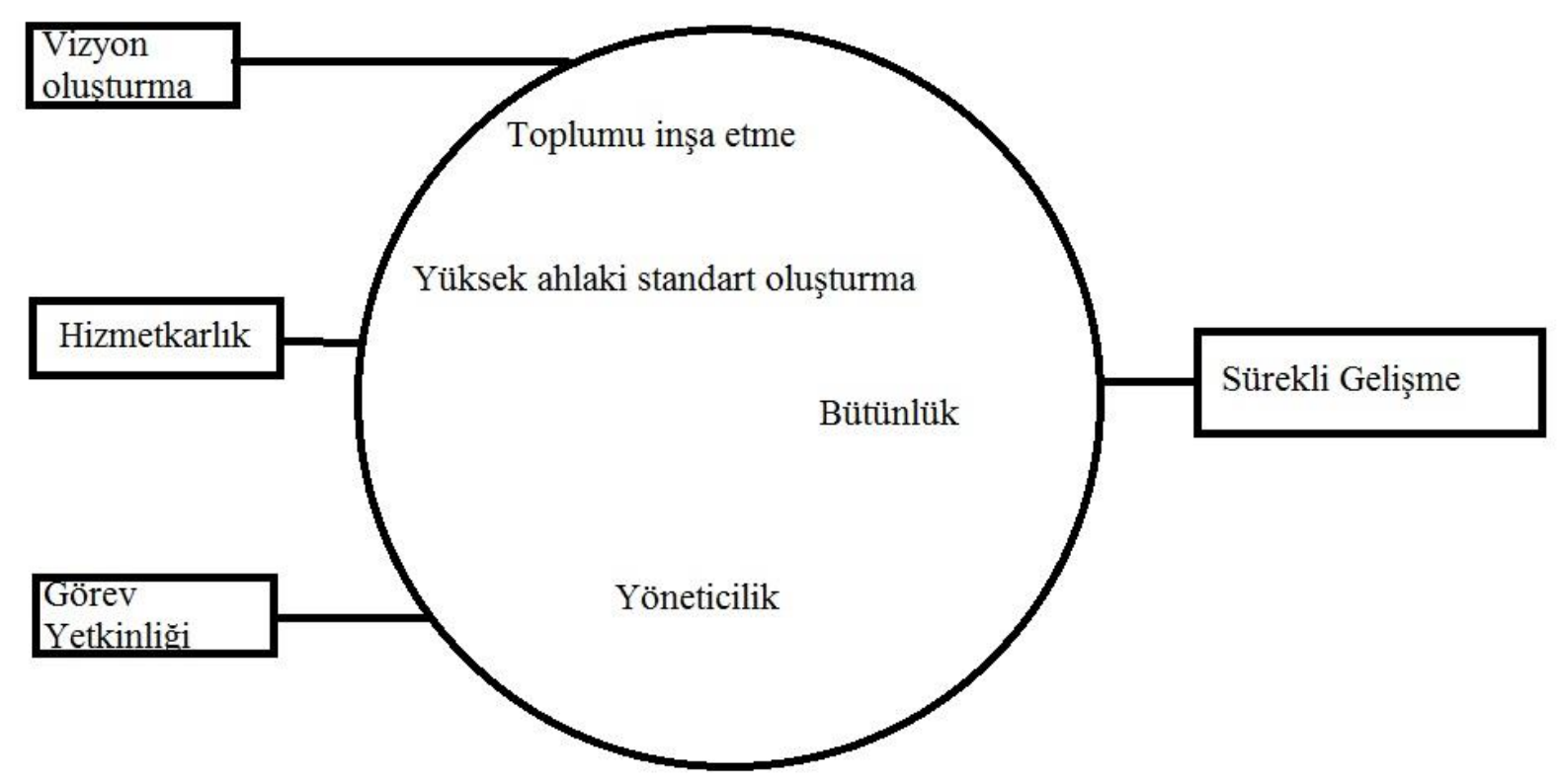

(Fairholm, 1998)

Bu model üzerindeki unsurları ve önemini Fairholm (1998) şöyle açıklamıştır:

Vizyon oluşturma: Liderlik anlam ve niyet oluşturmak ve paylaşmaktır. Bu bağlamda vizyonun kaynağı liderin kendi ruhsallık algısına bağlıdır. Vizyon memnuniyet, kapasite, sükûnet, tarafsızlık ve bağll1ıkla ilgilidir. Ruhsal liderler, vizyon ifadelerini birlikte hareket etme, ortak dikkat ve işe adanmışlı̆̆ın arttırılması üzerine hazırlarlar.

Hizmetkarlık: Liderler önderlik ederler çünkü onlar diğerlerine hizmet etmeyi seçmişlerdir. Onlar takipçilerine bilgi, zaman, dikkat, materyal vb. kaynaklar sağlarlar. İşi anlamlı hale getirir ve yüksek iş birliği ortamı oluştururlar. Hizmete dayalı liderlik de bu noktada liderlerden kişilerin kendi liderliğini oluşturduğu ortamı yaratmasının mümkün kılmasını ya da bu ortamın oluşmasını kolaylaştırıcı işler yapmasını bekler.

Görev Yetkinliği: Kendilerine güvenen ve kendi ahlaki doğruluklarına inanan ruhsal liderler bu özellikleri takipçilerine de transfer ederler. Bu kendine güvenin oluşabilmesi de liderin öğretme, güvenme, heveslendirme ve gerçek bir görev ya da iş hakkında bilgi edinme yetkinliğinin olması gerekir.

Toplumu inşa etme: Toplumu inşa etmede ruh temelli liderin işi farklı, zıt insanların, toplulukların ve sistemlerin uyumlaştırılmasını sağlamak, bu farklı grupların birlikte hareket etmesini sağlayabilmektir. Bunu yaparken de paydaşların hepsinin kabul edilebilir bulacağı, paydaşlara enerji verebilecek değerleri, inançları ve hareket prensiplerini bir arada toplamak gerekir.

Bütünlük: Ruhsal liderin derdi insanların tüm yönleridir, sadece şu ya da bu özel işe yarar yeteneği değildir. Takipçilerin şimdi yapabildiğinin yanında, ne yapmak istediği, kapasitesinin ne olduğu da tümüyle ruhsal lideri ilgilendirir.

Yüksek ahlaki standart oluşturma: Ruhsal liderler örgütleri için belli bir ahlaki seviye oluşturmaya çalışırlar. Liderlik, diğerlerini anlamaya çalışmak ve insan davranışının seviyesini yükseltici paylaşımlar yapmaktır. 
Yöneticilik: Liderler bilirler ki onların liderliği geçici bir süre güvendedir. Onlar planlar, seçenekler ve programlar hazırlayabilirler. Fakat zaman zaman takipçiler bu programa gerek kalmadan bile sürece uyum sağlayabilirler. Liderler, grupları için değerler kümesi oluştururlar ve bu değerleri kendi davranışlarına da yansıtarak takipçilerine model olurlar.

Sürekli Gelişim: Liderin tek hedefi sürekli daha iyi olmaktır. Bu da kafa ve elin çalışmasından çok, kalbin iyi eğitilmesiyle olur.

Ortaya atılan bir diğer ruhsal liderlik modeli de Fry'ın modelidir. Fry (2003), değerler tutumlar ve davranışları kişi ve çevresindekilerin ruhsal liderliği hissedebilmesi için gerekli motivasyon sağlayıcısı olarak görmektedir. Bu nedenle Fry'a (2003) göre ruhsal liderlik, örgüt üyelerinde hayatlarının daha anlamlı olduğu ve hayatlarının farklılaştığı hissini yaratan bir vizyon oluşmasına sebep olur. Ayrıca bu liderler ve takipçilerinin kendilerinin gerçekten önemli olduğu hissinin oluştuğu özgeci bir sevgiye dayalı örgüt kültürünün oluşmasını sağlar. Kişiler kendilerinin örgütün üyesi olduklarını ve orada anlaş1lıp takdir edildiklerini daha iyi hissederler (Fry, 2003). Fry'ın ortaya attı̆̆ modele göre, kişinin kendi içsel motivasyonunu sağlaması için ruhsal liderlik önemlidir.

Fry ortaya attığı ruhsal liderlik modelini zaman içinde daha da geliştirmiştir. Bu gelişim sürecinde Melanie P. Cohen, Eleftheria (Ella) Egelve Melissa S. Nisiewicz gibi çalışma arkadaşlarını da çalışmasına dahil etmiştir. Fry ve Cohen (2008), ruhsal liderliği bireysel ve örgütsel çıktılar açısından ele almış ve içsel yaşantıyı da ruhsal liderlik tabanına oturtarak aşağıdaki modeli oluşturmuşlardır.

\section{Şekil 2 Ruhsal Liderlik Modeli}

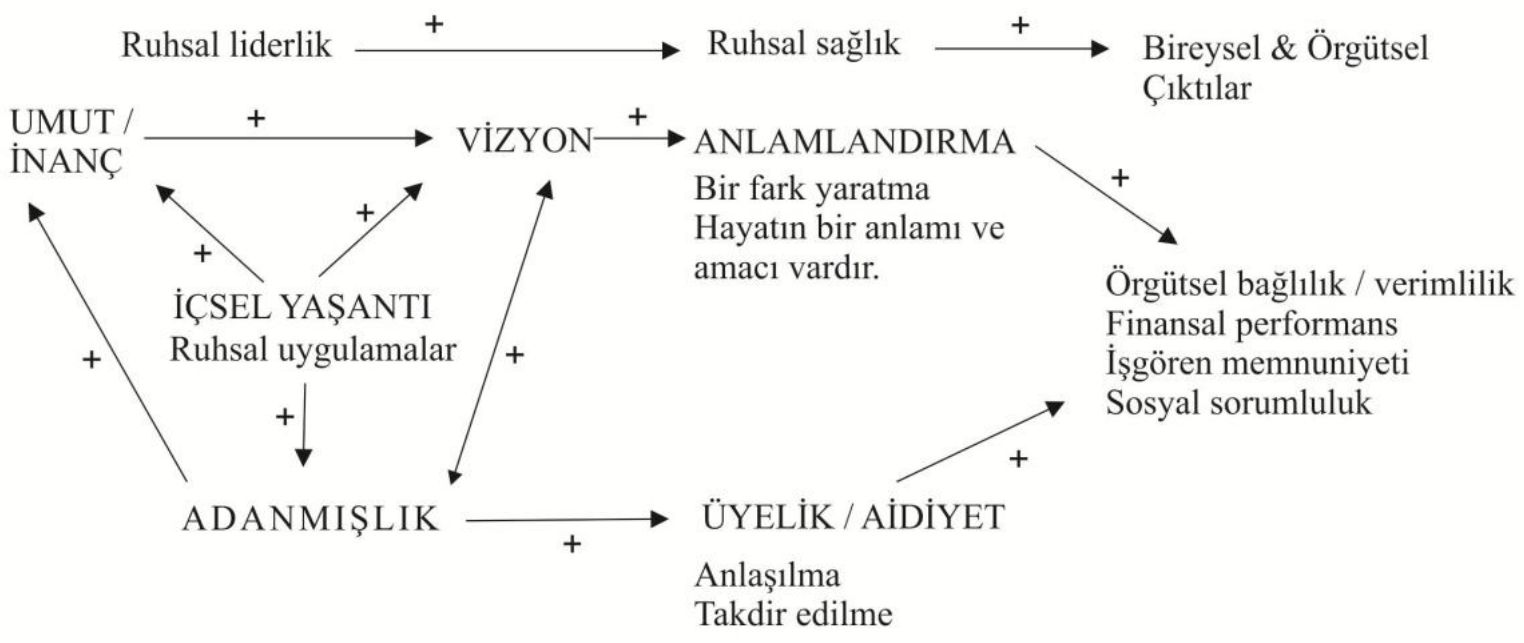

(Fry \& Cohen, 2008; akt. Korkut, 2012)

Fry ve arkadaşlarına göre içsel yaşantıyı temele alan ruhsal liderlik umut-inanç, vizyon ve adanmışlığın etkileşiminden ortaya çıkar. Ruhsal liderliğin temelini oluşturan bu kavramların içeriği şöyledir (Fry, Egel \& Nisiewicz, 2016):

Umut ve İnanç: Umut bir şeyin yerine getirilmesi ya da olma arzusudur. İnanç ise umuda biraz daha kesinlik katar. İkisi beraber ele alındığında ise kanıtı olmayan bir şeye katı bir şekilde inanma gerçeği ortaya çıkar. Değerler, tutumlar, kesin gerçeğin sergilendiği davranışlar, arzu edilen ve umulan şeyin olacağına olan güvene dayanır. İnancı ve umudu olan bireylerin nereye gittiği ve oraya nasıl varacağı hakkında bir vizyonu vardır. Onlar hedeflerine giderken zorluklarla karşılaşmaya razıdırlar. Umut ve inanç ayrıca yerine getirilecek kişisel ya da örgütsel vizyonun gerçekleştirilmesine kanaat getirmek için kaynaktır. Eylemde umut ve inanç zafer ve yarışa hazırlanma gibi düşünülebilir.

Vizyon: Vizyon insanların neden o geleceği yaratmak için gayret etmesi gerektiğini açıkça ya da üstü kapalı bir şekilde yorumlayan gelecek resmidir. Fry ve arkadaşlarına göre, vizyon değişim yolunda üç önemli fonksiyona hizmet eder. Bu üç fonksiyon, genel değişim yönünü açıklaması, çok sayıda detaya açıklık getirmesi ve grup üyelerinin hareketlerini hızlı ve verimli bir şekilde koordine etmesidir. Bunun yanında işgörenlerin işe olan enerjisini arttırır, işi daha anlamlı kılar ve mükemmeliyet 
için bir standart oluşturur. İnsanları bir iş için harekete geçirmede vizyonun ciddi bir cazibesi olmalıdır, örgütün varış noktasını iyi tanımlamalı, yüksek idealleri tanımlayıp, umut ve inanca onları teşvik etmelidir.

Adanmışlık: Ruhsal liderlikte adanmışlık bir bütünlük hissi, uyum ve hem kendisi hem de diğerleri için dikkat etme, kaygı duyma ve taktir etme yoluyla oluşan iyi olma durumu olarak tanımlanır. Adanmışlık kızgınlık, üzüntü, korku gibi olumsuz duyguların üstesinden gelecek sevgiyi de içerir. Adanmışlık grup üyeleri tarafından paylaşılan ve gruba yeni eklenenlere de öğretilen ahlaki olarak doğru olduğu düşünülen önemli değerleri, çıkarımları, anlayışları ve düşünme şekillerini de kapsar. Ruhsal liderler bu değerleri şekillendirir ve onlara günlük yaşamlarında da uyarlar.

İçsel Yaşantı: Örgüt üyelerinin her birisinin fiziksel, akli ve duygusal ihtiyaçlarının yanında ruhsal ihtiyaçları da vardır. Bu ruhsal ihtiyaçlar kişinin içsel yaşantısının bir parçasıdır. İçsel yaşantı da ruhsal liderliğin önemli bir kısmını oluşturur.

Fry, Egel ve Nisiewicz'e (2016) göre, ruhsal liderlikte takipçiler için önemli iki nokta vardır. Bunlar, anlamlandırma ve üyelik / aidiyettir. Bu iki kavramın doğru anlaşılabilmesi açısından Fry ve arkadaşlarının tanımlamalarına bakılacak olursa:

Anlamlandırma: Anlamlandırma bazı şeyleri aşma ya da başkaları için çalışma konusunda fark yaratma ve bunu yaparken yaşamın anlamını ve amacını bulma anlamlarında kullanılabilir. Anlamlandırma sözcügü profesyonellerin özelliklerini tanımlarken de kullanılan bir sözcüktür. Profesyonellik kalite standartlarını korumayı ve işine bağlı olmayı gerektirir. Bu profesyonellik iş paylaşımı ile daha kolay gerçekleşir ve kişi kendi işini değerli ve önemli görür. Değerli gördüğü (anlamlandırdığı) bu işin bağlı olduğu birim de onun için önemli hale gelir ve kişi bağlı olduğu birimde bulunmaktan gurur duyar. Ruhsal liderlikte de anlamlandırma adına bu görev paylaşımı ve hedef tanımlamas1 yapilır.

Üyelik / Aidiyet: Üyelik bir topluluğa mensup olma ve ait olma durumudur. İnsanın en önemli psikolojik ihtiyaçlarından birisi de, anlaşılma ve takdir edilmedir. Bu anlaşılma ve takdir edilme ihtiyacı kişinin bulunduğu bir grupta meydana gelmesi kişiyi daha güçlü hale getirir. Bu kişinin bulunduğu grup güçlendikçe ve yayıldıkça kişi kendisini daha güçlü hisseder.

\section{Yapılan Araştırmalar}

Ruhsal liderlikle ilgili dünyada yapılmış birçok çalışma vardır, çünkü ruhsal liderliğin temelini oluşturan ruhsallığın gizemli yapısı insanların hep merakını uyandırmıştır. Fairholm'un (1998) araştırmaları ruhsal liderliği derli toplu hale getirmiştir ve ruhsal liderlik kuramı diğer araştırmacılar için temel oluşturmuştur. Fry (2003) da ruhsal liderlik için ciddi emek sarfetmiştir. Fry, Egel ve Nisievicz (2016) ile ruhsal liderliği bir internet sitesi üzerinde kapsamlı bir şekilde tanıtmışlar ve gelişime açık hale getirmişlerdir. Fry, Hannah, Noel ve Walumbwa (2011), ruhsal liderlik ile ruhsal sağlık arasındaki ilişkiyi ve askeri liderlerden oluşan örneklemde ruhsal liderliğin örgütsel sonuçlarını araştırmışlardır. Yapısal eşitlik modelinin kullanıldığı bu çalışmada ruhsal liderlik ile örgütsel bağlılık ve dört performans düzeyinin de içinde bulunduğu birkaç davranış sonucu arasında pozitif ve anlamlı bir ilişki bulunmuştur. Parameshwash (2005), kendini aşma yoluyla ortaya konulan ruhsal liderliği araştırmıştır. $\mathrm{Bu}$ araştırmayı sosyal sorunlara karşı kendi çıkarını bir kenara bırakan 10 lider üzerinde yapmıştır. Parameshwash bu liderleri, otobiyografileri ve konuşmalarından alınmış 504 olay üzerinden incelemiş, onların özelliklerini tablo haline getirmiş ve farklı farklı kıta, zaman, din, eğitim düzeyi ve profesyonellik düzeylerinden alınan bu liderlerin zor durumlara karşı şiddet içermeyen, kendi çıkarlarının ötesine geçen, ruhsal müdahalelerini incelemiştir. Araştırmanın sonucu liderlerin çözmeye çalıştığ sorunlar, yaşadığ zamanlar, yerler her ne kadar farklı olursa olsun, sergiledikleri barışçıl tutumun olumlu etki göstereceği şeklinde olmuştur.

Türkiye'de ruhsal liderlik ile ilgili yapılmış az sayıda çalışma vardır. Baloğlu ve Karadağ (2009), ruh ve ruhsallık arasındaki bağlantılara dayanarak ruhsal liderliği açıklamaya çalışmıştır. Baloğlu ve Karadağ (2009), ruhsal liderlik üzerine çok fazla ampirik çalışma yapılmadığını bundan dolayı da bu konuyla ilgili yapılacak yorumlara çok dikkat edilmesi gerektiğini belirtmektedirler. Bu 
araştırmacılar, ruhsal liderliğin, bir liderlik türü olmasından çok bir liderlik stratejisi olabileceğini görüşünü kabul etmektedirler.

Aslan ve Korkut (2015), Türkiye'deki İlkokullarda öğretmenlerin ruhsal liderlik algılarını araştırmışlardır. Bu araştırmanın sonuçlarına göre ilkokul öğretmenlerinin okullarında ruhsal liderliğin alt boyutları, anlamlandırma, içsel yaşantı ve umut/inanç açısından iyi düzeydedirler. Öğretmenlerin işlerinin önemli ve anlamlı olduğunu düşündükleri, hayat hakkında umutlu oldukları ve ruhsal sağlığa dikkat ettikleri görülmüştür. Ancak öğretmenlerin hayattan memnuniyetleri, vizyonları, aidiyet durumları ve örgütsel bağl1lıkları açısından daha aşağı düzeyde olduğu görülmüştür. Karadağ (2009) ilköğretim okul müdürlerinin öğretmenler tarafindan algılanan ruhsal liderlik davranışları ve örgüt kültürü arasındaki ilişkiyi araştırmıştır. Araştırma sonucuna göre, ilköğretim okulu müdürlerinin huzura yönelik davranışları arttıkça, örgüt kültürü düzeyi hakkındaki öğretmenlerin algıları artmakta ve benzer şekilde performansa yönelik davranışlar arttıkça öğretmenlerin örgüt kültürü algıları artmaktadır. İlköğretim müdürlerinin huzura ve performansa yönelik davranışları, öğretmenlerin örgüt kültürünün değişkenleri olan idari, sosyal, değer ve amaç boyutlarının olumlu olarak algılanmasını sağlamaktadır. Aydın ve Ceylan (2009), ruhsal liderliğin örgütsel öğrenme kapasitesini etkileyip etkilemediğini araştırmıştır. $\mathrm{Bu}$ araştırmayı metal işleri fabrikasında çalışan işçiler üzerinde yapmışlardır. Araştırma sonucuna göre metal endüstrisindeki örgütsel öğrenme kapasitesiyle ruhsal liderlik arasında düşük düzeyde pozitif ilişki bulunmuştur. Bunun nedeninin de metal işleri endüstrisi örgütlerinin ruhsal yönden çok parasal eğilime sahip olduğu sonucuna varılmıştır. Gündüz (2014), inşaat, bilişim, gıda ve sigortacılık sektöründe ruhsal liderlik ile örgütsel sinizm arasındaki ilişki ve duygusal zekânın buna etkisini araştırmıştır. Araştırmada ruhsal liderliğin örgütsel sinizmi azaltıcı bir rol oynadı̆̆ı, duygusal zekânın da ruhsal liderlik ile örgütsel sinizm arasında aracı rolü oynadığı sonucuna varılmıştır. Polat (2011) eğitim fakültesinde okuyan öğrencilere göre fakülte öğretim üyelerinin sergilediği ruhsal liderlik seviyesini araştırmıştır. Araştırma sonucuna göre öğrenciler akademik personelin orta seviyede ruhsal liderlik özelliği gösterdiğini düşünmektedirler.

Özgan, Bulut, Bulut ve Bozbayındır (2013) öğretmenlerin ruhsal liderlik algıları ile motivasyonları arasındaki ilişkiyi araştırmışır. Bu çalışmada, öğretmenlerin motivasyonları ile ruhsal liderlik algıları arasında yüksek düzeyde pozitif ve anlamlı bir ilişki bulunmuştur. Araştırmaya göre öğretmenlerin ruhsal liderlik algı düzeyleri arttıkça motivasyonları da artmaktadır. Çimen (2016), devlet okullarında çalışan öğretmenlerin ruhsal liderliğe ilişkin algıları ile örgütsel vatandaşlık davranışı arasındaki ilişkiyi incelemiştir. Bu çalışmada göre katılımcıların ruhsal liderlik algıları ile örgütsel vatandaşlık davranışları gösterme düzeyleri arasında anlamlı ve pozitif yönde bir ilişki saptanmıştır. Polat ve Tülübaş (2013), öğretim elemanlarının gösterdiği ruhsal liderlik davranışlarını üniversite öğrencilerinin görüşlerine göre belirlemişlerdir. Bu çalışmanın sonucuna göre, öğretim elemanları ruhsal liderlik davranışını yüksek düzeyde göstermektedirler. Bozkurt ve Töremen (2015) okul müdürlerinin ruhsal liderlik yeterliliklerinin öğretmenlerin örgütsel vatandaşlık davranışları üzerindeki etkisini araştırmıştır. Bu çalışmanın sonucuna göre, okul müdürlerinin ruhsal liderlik yeterlilikleri ve öğretmenlerin örgütsel vatandaşlık davranışları arasında orta düzeyde pozitif anlamlı bir ilişki vardır. Ruhsal liderliğin arttığı ortamlarda liderin sağladığı kayıtsız şartsız özgecil sevgi, o ortamdaki endişe, kızgınlık, kıskançlık, bencillik, başarısızlık, suçluluk gibi duygulardan kaynaklanan korkuların ortadan kalkmasında işlev görecek ortak bir vizyon yaratılmasına yardımcı olur (Polat \& Tülübaş, 2013). Oluşturulacak bu ortak vizyon da örgütün bir bütün halinde hareket etmesine yardımcı olacak ve karar alma sürecini kolaylaştıracaktır. Bu durum eğitim örgütleri için düşünüldüğünde, ortak kararların öneminin daha da ön planda olduğu açıktır. Çünkü ruhsal liderlik çalışanların iç dünyalarının düşüldüğü bir liderlik modelidir. Ruhsal liderlik genel özellikleri itibariyle bireylerin iç dünyasını ele alıp duygu ve düşüncelerini önemseyerek örgüt üyelerinin ruhsal olarak daha güçlü olmasını sağlamaktadır (Ertürk, 2016).

\section{Sonuç ve Öneriler}

Ruhsal liderlik, ruh kavramının derinlemesine incelenip liderlikle bağdaştırılması yoluyla anlamlı hale getirilmiştir. Her insanın bir iç dünyası vardır. İnsanları o iç dünyalarından ayrı düşünmek, insanın tüm yönlerini bir bütün olarak ele alınmaması ve insanın bütünlügünün bozulması anlamına 
gelir. İnsan için bu iç dünya, ruh ve içinde bulunulan durumda ruhsallık kavramlarıyla açıklanmıştır. Ruhsal liderlikte kişilerin bu iç dünyasına inme ve kişinin içinde bulunduğu örgüte ruhsal ve duygusal yönleriyle bağlanması söz konusudur. Ruhsal liderlikte yüksek verimlilik elde etmek, kişide sosyal sorumluluk duygusunu oluşturmak ve bunu yaparken de işgöreni memnun etmek başlıca amaçlardır. $\mathrm{Bu}$ amaçlara ulaşmak için de örgüt içinde bütünlük oluşturmak, belli ahlaki standartlara göre davranılmasını sağlamak, işgörenin içinde bulunduğu örgüte karşı aidiyet duygusuna sahip olmasını sağlamak, işgören için yaptığ 1 işi anlamlı hale getirmek önemli unsurlardır.

Ruhsal liderliğin bir örgütte sağlıklı bir şekilde kullanılabilmesi için, örgüt üyelerinin içsel yaşantılarına her zaman dikkat edilmesi gerekir. Örgüt içindeki kişilerin kendilerini örgütün üyesi olarak hissedebilmesi, hem kendisi hem de örgütteki diğer üyeleri düşünüp onlar için de dikkat etmesi ya da kaygı duyması, örgüt içinde takdir etme ve edilme hissini yaşaması örgüt üyelerinin aidiyet hissini arttıracaktır. Örgüt içinde yapılan işin önemi öne çıkarılıp kişinin yaptığ 1 işe olan inancı arttırılarak, kişilerin o iş için harekete geçmesi ve içten denetimli bir şekilde çalışması sağlanabilir.

\section{Kaynakça}

Aslan, M., \& Korkut, A. (2015). Spiritual leadership in primary schools in Turkey. Journal of Educational and Social Research, 5(2), 123-136.

Aslan, Ş. (2013). Geçmişten günümüze liderlik kuramları . Konya: Eğitim Kitabevi.

Aydın, B. ve Ceylan A. (2009). The effect of spiritual leadership on organizational learning capacity. African Journal of Business Management,3(5),184-190

Baloğlu, N., \& Karadağ, E. (2009). Ruhsal liderlik üzerine teorik bir çözümleme. Kuram ve Uygulamada Egitim Yönetimi, 165-190

Bass, B. M. (1990a). Bass and stogdill's handbook of leadership; Theory, research and managerial applications (3. b.). New York: The Free Press.

Bass, B. W. (1990b). Form transactional to transformational leadership: Learning to share the vision. Elsevier inc.

Bozkurt, B., \& Töremen, F. (2015). An investigation of the effect of school principals' spiritual leadership competencies on teachers' organizational citizenship behaviours. Electronic International Journal of Education, Arts, and Science, 1(2), 181-200. Ağustos 4, 2016 tarihinde http://www.eijeas.com adresinden alınd1.

Bozkuş, K., \& Gündüz, Y. (2016). Ruhsal liderlik ile örgütsel bağl1lık arasındaki ilişkinin modellenmesi. Kastamonu Eğitim Dergisi, 24(1), 405-420.

Çimen, i (2016). Öğretmenlerin Ruhsal Liderliğe İlişkin Algıları ile Örgütsel Vatandaşlık Davranış1 Gösterme Düzeyleri Arasındaki İlişki. Dicle Üniversitesi Ziya Gökalp Eğitim Fakültesi Dergisi, (27), 9-19

Ertürk, A. (2016). Hizmetkar Liderlik, Ruhsal Liderlik ve Kuantun Liderlik. Nezahat Güçlü (Ed.), Eğitim Yönetiminde Liderlik: Teori, Araştırma ve Uygulama içinde. Ankara Pegem Akademi.

Fairholm, G. W. (1998). Perspectives on leadership: From the science of management to its spiritual heart. United States of America: Greenwood Publishing Group.

Fry, L. W. (2003). Toward a theory of spiritual leadership. The Leadership Quarterly, 693-727.

Fry, L. W., \& Cohen, M. P. (2008). Spiritual leadership as a paradigm for organizational transformation and recovery from extended work hours cultures. Journal of Business Ethics(84), 265-278.

Fry, L. W., Egel, E., \& Nisiewicz, M. S. (2016). What Is Spiritual Leadership? International Institute for Spiritual Leadership: http://iispiritualleadership.com adresinden alındı

Fry, L. W., Hannah, S. T., Noel, M., \& Walumbwa, F. O. (2011). Impact of spiritual leadership on unit performance. The Leadership Quarterly, 259-270. 
Güçlü, N. (2016). Liderliğe genel bir bakış. N. Güçlü içinde, Eğitim Yönetiminde Liderlik; Teori, Araştırma ve Uygulama (s. 1-15). Ankara: Pegem Akademi .

Gündüz, Ş. (2014). Ruhsal liderlik ile örgütsel sinizm arasındaki ilişki: Duygusal zekânın aracı etkisi. Yayımlanmamış doktora tezi. Marmara Üniversitesi - Sosyal Bilimler Enstitüsü. İstanbul.

Hill, P. C., Jurkiewicz, C. L., Giacalone, R. A., \& Fry, L. W. (2015). From concept to science: Continuing steps in workplace spirituality research. R. Paloutzian F., \& C. L. Park içinde, Handbook Of The Psychology Of Religion and Spirituality (s. 617-631). U.S.A: Paperback Edition.

Karadağ, E. (2009). Ruhsal Liderlik ve Örgüt Kültürü: Bir Yapısal Eşitlik Modelleme Çalışması. Kuram ve Uygulamada Ë̆itim Bilimleri, 9(3)1357-1405

Keskinkılıç Kara, S. B. (2013). Yeni bilim ve liderlik. Akademik bakış dergisi. (34),1-13.

Korkut, A. (2012). Ruhsal liderliğe ilişkn kuramsal bir inceleme. Malatya: İnönü Üniversitesi.

Özgan,H.; Bulut, L.; Bulut, A. ve Bozbayındır, F. (2013). Öğretmenlerin ruhsal liderlik algıları ile motivasyonları arasındaki ilişkinin incelenmesi. Uşak Üniversitesi Sosyal Bilimler Dergisi, 6(1).70-83

Parameshwar, S. (2005). Spiritual leadership through ego-transcendence: Exceptional responses to challenging circumstances. The Leadership Quarterly (16), 689-722.

Polat, S. (2011).The level of faculty members' spiritual leadership qualities display according to students in faculty of education. Procedia Social and Behavioral Sciences 15,2033-2041.

Polat, S \& Tülübaş, T. (2013). Üniversite Hazırlık Sınıfı Öğrencilerine Göre Öğretim Elemanlarının Ruhsal Liderlik Davranışlarını Gösterme Düzeyleri. Eğitim ve Bilim, 38(170), 32-47

Wharff, D. M. (2004). Expressions of spiritually inspired leadership in the public sector: Calling for a new paradigm in developing leaders. Maryland: University of Maryland University College.

Zafer Güneş, D. ve Keskinkılıç Kara, S. B. (2017). Özel Okullarda Yetenek Yönetimi Uygulamaları. Sakarya University Journal of Education, 7(1), 142-154

Zaleznik, A. (1977). Managers and leaders; Are they different? Harward Business Review, 1-10 